\title{
Foreign Direct Investment and Regional Inequality in China
}

\author{
Kailei Wei, ${ }^{1}$ Shujie Yao, ${ }^{2}$ and Aying Liu ${ }^{1}$
}

October 2008

\begin{abstract}
China's economic miracle over the past three decades has been featured with its open-door policy, especially the absorption of foreign capital. One downside effect of economic reform has been the ever rising interregional inequality. As FDI is highly unevenly distributed across regions, many scholars and policymakers have blamed their inflows as one of the main factors driving the Chinese regions apart. If this logic were true, then controlling the scale of FDI could be a solution to reduce regional inequality. However, it is difficult to reconcile the positive effect of FDI on economic growth with its potential 'negative' effect on regional inequality. This is a controversial and provocative issue in the economic development literature. Using the largest panel dataset covering all the Chinese regions over the entire period 1979-2003 and employing an augmented Cobb-Douglas production function, this paper proves that FDI has been an important factor responsible for regional growth differences in China. However, it suggests that FDI cannot be blamed for causing regional inequality; it is the uneven distribution of FDI instead of FDI itself that has caused regional growth differences. The key policy issue is that FDI should be guided towards the inland areas with preferential policies in order to improve the spatial allocation of investments as a means to reduce regional inequality.
\end{abstract}

Keywords: foreign direct investment, regional inequality, China

JEL classification: O11, O57, F43

\section{Copyright $\mathbb{0}$ UNU-WIDER 2008}

${ }^{1}$ University of Middlesex Business School, London: email: k.wei@mdx.ac.uk (K. Wei); a.liu@mdx.ac.uk (A. Liu); ${ }^{2}$ (corresponding author) School of Contemporary Chinese Studies, University of Nottingham, Nottingham; email: Shujie.yao@nottingham.ac.uk (S. Yao)

This study has been prepared within the UNU-WIDER project on the Southern Engines of Global Growth, co-directed by Amelia U. Santos-Paulino and Guanghua Wan.

UNU-WIDER gratefully acknowledges the financial contributions to the research programme by the governments of Denmark (Royal Ministry of Foreign Affairs), Finland (Ministry for Foreign Affairs), Norway (Royal Ministry of Foreign Affairs), Sweden (Swedish International Development Cooperation Agency_Sida) and the United Kingdom (Department for International Development). 


\section{Acronyms}

CV coefficient of variation

FDI foreign direct investment

SEZs special economic zones

The World Institute for Development Economics Research (WIDER) was established by the United Nations University (UNU) as its first research and training centre and started work in Helsinki, Finland in 1985. The Institute undertakes applied research and policy analysis on structural changes affecting the developing and transitional economies, provides a forum for the advocacy of policies leading to robust, equitable and environmentally sustainable growth, and promotes capacity strengthening and training in the field of economic and social policy making. Work is carried out by staff researchers and visiting scholars in Helsinki and through networks of collaborating scholars and institutions around the world.

www.wider.unu.edu

publications@wider.unu.edu

UNU World Institute for Development Economics Research (UNU-WIDER)

Katajanokanlaituri 6 B, 00160 Helsinki, Finland

Typescript prepared by Liisa Roponen at UNU-WIDER

The views expressed in this publication are those of the author(s). Publication does not imply endorsement by the Institute or the United Nations University, nor by the programme/project sponsors, of any of the views expressed. 


\section{Introduction}

Since economic reform and the open-door policy in the late 1970s, China has achieved impressive economic growth at an annual rate of 9.6 per cent during 1978-2006. By 2005, China was the fourth biggest economy in the world measured in nominal dollars and the second largest measured in PPP dollars. However, China's economic integration with the world has been accompanied by growing regional inequality. Different regions have not enjoyed equally the fruits of economic reform. Statistics show that the Gini coefficient measuring China's household income inequality increased from 0.300 in 1984 to 0.45 in 2000 and continued to rise into the twenty-first century. China has stepped into the stage of 'absolute disparity' (Chang 2002).

High economic growth and rising disparity in China's regions attract serious attention. Researchers debate on whether regional inequality has intensified and on what has contributed to the inequality in post-reform China. Many studies suggest that government policies favouring the coastal region have worsened regional income inequality, arguing for more resources to be allocated to the disadvantaged areas (Lakshmanan and Hua 1987; Kueh 1989; Cannon 1990; Yang 1990, 1991; Kato 1992; Chai 1996; Yao 1999; Yao and Zhang 2001a, 2001b; Fu 2004; Chen and Wu 2005).

However, not all studies agree with the view that regional inequality has widened in the post-reform period. They argue instead that regional inequality has actually declined since the adoption of economic reforms, mainly as a result of diffusion, convergence, interregional resource transfer, and rural industrialization. Hsueh (1994) argues that national economic policies tended to redistribute capital from rich to poor regions in the 1980s, thereby generating a process of convergence. Gundlach (1997) finds absolute convergence in regional output per worker across Chinese regions in 1978-89. Raiser (1998) also notes similar evidence of absolute convergence using regional data in 1978-92. Huo (1994) and Chen and Fleisher (1996) observe similar results.

Some other studies show two opposite trends of regional inequality in China at different periods. For example, Lyons (1991) and Tsui (1991) show a slight decline in inequality during 1978-87 and an increase in inequality by comparing the early 1980s with the 1950s. Sachs and Warner (1996) find evidence of convergence from 1952 to 1965 and divergence from 1965 to 1978. Since the late 1980s, however, Sachs and Warner observe a widened income gap between coastal and non-coastal regions. Furthermore, they find that intra-regional disparities declined during the reform period but interregional inequality experienced little improvement. Jian, Sachs and Warner (1996) argue that real income convergence of Chinese provinces was a relatively recent phenomenon, emerging strongly only since the reform period began in 1978. After 1990, however, regional incomes diverged again. Tsui (1996) shows that inequality across different provinces in China declined in the first half of the 1980s, but deteriorated again from the second half of the 1980s.

The controversial arguments above may be due to the different approaches and data periods. Compared to other empirical studies of foreign direct investment (FDI) issues in China, relatively few studies have provided a detailed assessment on FDI and regional economic inequality. However, there are some scholars who have attempted to do so. Most of the arguments in earlier studies claim that FDI leads to more poverty, isolation, a neglect of local capabilities and larger inequality (Mazur 2000). Sun and 
Chai (1998) examine the effects of FDI on economic growth in the eastern and western regions of China by using panel data across 16 provinces over 1986-92. They discover that the effect of FDI on economic growth was stronger in the eastern region and very weak in the western region, which reinforced interregional economic inequality. Bao et al. (2002) investigate the effect of geography on regional economic growth in China during 1978-97. They claim that the coastal regions had spatial and topographic advantages characterized by possessing more FDI and mobilization of rural surplus labour plus lower costs of transportation and communication, which produced the disparity from coastal to inland regions. Zhang and Zhang (2003) develop an empirical method for decomposing the contributions of two major driving forces of globalization, foreign trade and FDI on regional inequality and apply it to China in 1986-98. Globalization is found to be an important factor contributing to the widening regional inequality. More recently, $\mathrm{Fu}$ (2004) investigates the spillover and migration effects of exports and FDI and estimates their impact on regional income inequalities in China and finds that exports and FDI played an important role in raising regional disparities. In contrast, some studies bring out opposite evaluations about FDI. Dollar and Kraay (2002) argue that the current wave of FDI from the 1980s promoted equality and reduced poverty. Zhang (2001) investigates the role of trade and FDI in a cross-country convergence analysis, indicating that export and FDI tend to accelerate the convergence process in the Asian newly industrialized economies and Japan.

The controversial empirical studies on the linkage between FDI and regional inequality require further research. Yao and Wei (2007) claim that FDI has played a dual role on economic growth as a mover of production efficiency and a shifter of production frontier. FDI is hence regarded as a powerful driver of economic growth for China in catching up with the most advanced countries in the world. Consequently, it is expected that the less developed regions of China such as the west and central provinces might be able to catch up with their rich east counterparts with more FDI. This paper estimates quantitatively the linkage of FDI inflow and economic inequality in China's regions using more recent data, and examines whether and how FDI has contributed to the process of convergence or divergence of income across the Chinese regions.

In relation to the per capita income gap within China, a series of studies have contributed to the evolution of income distribution in China during the pre- and postreform periods. One group of articles has decomposed the Gini coefficient of mainland China in order to explain the causes of income inequality, and find that rural-urban inequality and spatial inequality are the causes of such inequality (Tsui 1996; Yao 1999; Yao and Zhang 2001a; Gustafsson and Shi 2002). Some articles employ the classical approach and the concepts of $\beta$ - and $\sigma$-convergence to address the spatial pattern of China's economic growth and income inequality (Jian, Sachs and Warner 1996; Gundlach 1997; Raiser 1998; Démurger 2001; Zhang 2001; Yao and Zhang 2001b). In this study, the $\sigma$ - and $\beta$-convergence tests in absolute and conditional convergence with respect to per capita real GDP will be applied.

The next section presents the background information on Chinese regional inequality with FDI distribution. Section 3 presents the empirical models and data definition. Section 4 interprets the empirical results, and section 5 concludes with policy implications. 


\section{Regional inequalities in China after economic reform}

Economic reforms over the past three decades have brought about exciting growth prospects throughout China, especially for some provinces in the coastal region. During 1979-2003, real per capita GDP increased more than eight-fold, registering an average annual growth of 9.41 per cent, while that of the east, central and west were 10.17 per cent, 8.5 per cent and 8.05 per cent, respectively. 1 The highest growth provinces are concentrated in the eastern coast which possesses advantages of geography, endowments, and preferential policies, such as the establishment of the special economic zones (SEZs) and open coastal cities, as well as other incentive policies of attracting foreign investments. At the same time, the industrialization policies towards the central and western regions were removed. All of these have allowed the coastal region to grow much faster than the other regions of the country. Consequently, the Chinese economy has experienced unprecedented rapid and steady growth with increasing interregional disparity, which deteriorated particularly after the 1990s. The ratio of east-central-west per capita real GDP was 1.71:1.23:1 in 1979, 2.03:1.15:1 in 1992, and rising to 2.98:1.56:1 in 2005 .

The regional disparity in China can be attributed to many factors such as different natural resources, human capital endowments, infrastructure and transportation, geographical location, proximity to foreign markets and investors, economic structures, coast-oriented regional policy and foreign direct investments. Among these factors, uneven distribution of resources and preferential policies given to the east are widely regarded as the dominant causes of regional inequality in China.

Figure1

Real per capita GDP in comparison, 1979-2005 (yuan)

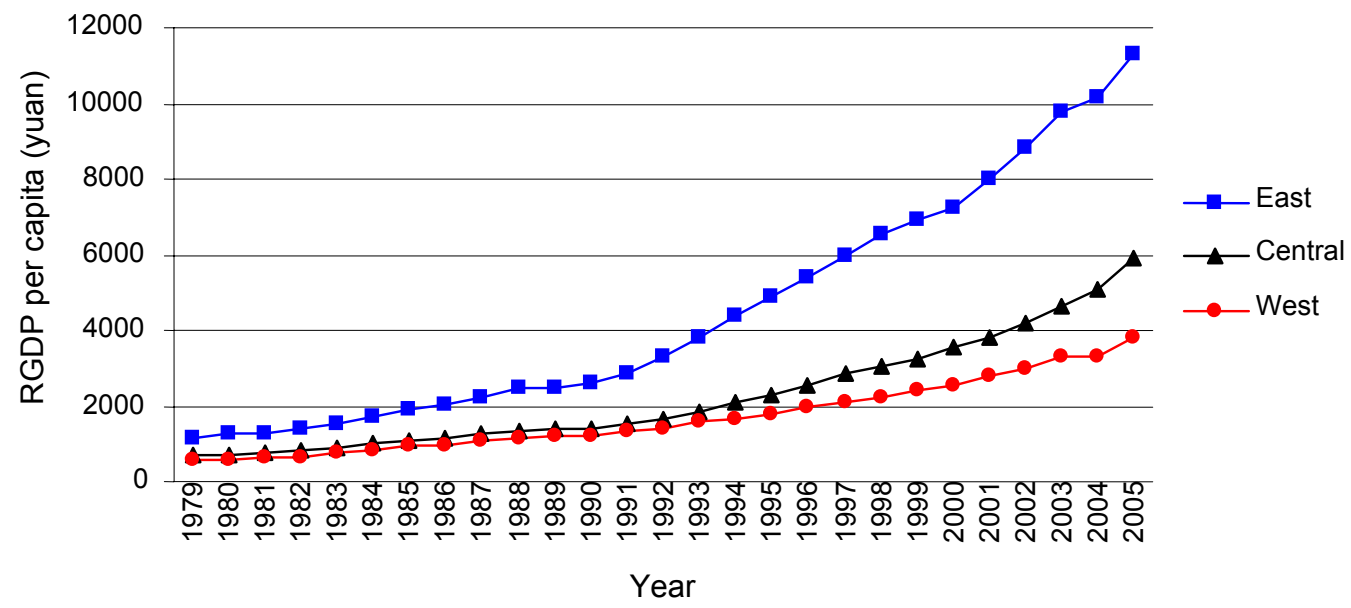

Note: $\quad$ Per capita GDP measured in 1990s prices.

Source: NBS (1999) and (NBS-CSY) various issues.

1 In this paper, east means the coastal eastern region, covering Beijing, Tianjin, Liaoning, Shanghai, Jiangsu, Zhejiang, Fujian, Shandong, Guangdong (Hainan), Guangxi, and Hebei. Central means the central region, covering Shanxi, Inner Mongolia, Jilin, Heilongjiang, Anhui, Jiangxi, Henan, Hubei, and Hunan. West means the western region, covering Sichuan (Chongqing), Guizhou, Yunnan, Shaanxi, Gansu, Qinghai, Ningxia, and Xinjiang. 
Figure 1 shows that the gap of real GDP per capita between the east and the inland region (the central and west regions combined) widened dramatically from 1992. Per capita incomes between the central and the west used to be very close but started to differ gradually in the following years as well.

The inflows of FDI into China started with a very low level in the 1980 s but rose dramatically after Deng's famous southern tour in 1992.

Before 1978, China virtually closed its door to foreign investments as a result of the Maoist ideology of 'self-sufficiency'. Since China's pursuit of the reform and openingup policy in 1978, FDI has gradually blossomed. FDI inflows into China increased sluggishly before 1992 and were mainly concentrated in a few coastal cities. As indicated in Table 1, FDI in China was only US\$0.92 billion in 1983 and grew slowly to US $\$ 4.37$ billion by 1991. However, FDI inflows expanded dramatically to US\$11 billion in 1992 and kept rising to US\$60.32 billion in 2005, making China the largest recipient of FDI in the developing countries after 1996 and then the biggest in the world in 2003. Meanwhile, China's GDP expanded sharply from RMB0.60 trillion in 1983, to 2.69 trillion in 1992 and to RMB18.31 trillion in 2005. The patterns of growth of

Table 1

FDI and GDP in China, 1983-2005

\begin{tabular}{|c|c|c|c|c|}
\hline Year & $\begin{array}{c}\text { FDI (US\$ billion) } \\
(1)\end{array}$ & $\begin{array}{c}\text { FDI (RMB billion) } \\
(2)\end{array}$ & $\begin{array}{c}\text { GDP (RMB billion) } \\
\text { (3) }\end{array}$ & $\begin{array}{c}\text { FDI/GDP (\%) } \\
\text { (4) }\end{array}$ \\
\hline 1983 & 0.92 & 2.69 & 596.27 & 0.45 \\
\hline 1984 & 1.42 & 4.17 & 720.81 & 0.58 \\
\hline 1985 & 1.66 & 4.87 & 901.60 & 0.54 \\
\hline 1986 & 1.87 & 6.47 & $1,027.52$ & 0.63 \\
\hline 1987 & 2.30 & 8.61 & $1,205.86$ & 0.71 \\
\hline 1988 & 3.19 & 11.89 & $1,504.28$ & 0.79 \\
\hline 1989 & 3.39 & 12.77 & $1,699.23$ & 0.88 \\
\hline 1990 & 3.49 & 16.68 & $1,866.78$ & 0.89 \\
\hline 1991 & 4.37 & 23.24 & $2,178.15$ & 1.07 \\
\hline 1992 & 11.01 & 60.70 & $2,692.35$ & 2.25 \\
\hline 1993 & 27.52 & 158.54 & $3,533.39$ & 4.49 \\
\hline 1994 & 33.77 & 291.03 & $4,819.79$ & 6.04 \\
\hline 1995 & 37.52 & 313.33 & $6,079.37$ & 5.15 \\
\hline 1996 & 41.73 & 346.91 & $7,117.66$ & 4.87 \\
\hline 1997 & 45.26 & 375.17 & $7,897.30$ & 4.75 \\
\hline 1998 & 45.46 & 376.39 & $8,440.23$ & 4.46 \\
\hline 1999 & 40.32 & 333.83 & $8,967.71$ & 3.72 \\
\hline 2000 & 40.72 & 337.06 & $9,921.46$ & 3.40 \\
\hline 2001 & 46.88 & 388.01 & $10,965.52$ & 3.54 \\
\hline 2002 & 52.74 & 436.55 & $12,033.27$ & 3.63 \\
\hline 2003 & 53.51 & 442.86 & $13,582.28$ & 3.26 \\
\hline 2004 & 60.63 & 501.82 & $15,987.83$ & 3.14 \\
\hline 2005 & 60.32 & 494.12 & $18,308.48$ & 2.70 \\
\hline
\end{tabular}

Notes: FDI in Column (1) and GDP in column (3) are measured in current price. Column (2) and (4) are calculated by the authors. Column (1) figures are converted to those in column (2) by using period average exchange rates. Column (4) equates Column (2) divided by Column (3).

Source: NBS (1999) and (NBS-CSY) various issues. 
FDI and GDP suggested a strong correlation between the two. This can be further confirmed by the ratio of FDI to GDP, as shown in column 5 in Table 1, which increased slightly from 0.45 per cent in 1983 to 1.07 per cent in 1991 , but doubled in 1992 to 2.25 per cent and reached a peak at 6.04 per cent in 1994 . However, this ratio gradually declined to only 2.7 per cent in 2005 .

GDP and FDI were highly concentrated in the east in the reform period (Figures 2 and 3). The east region accounted for over 52 per cent of China's GDP in 1979 and the share increased in the following consecutive 25 years. The west accounted for a small and declining share of China's GDP over the same period. The distribution of FDI across regions was more skewed than that of GDP. Over 86 per cent of China's FDI inflows were concentrated in the east. The other two regions were responsible for just 14 per cent.

Figure 2

Shares of real GDP by region, 1979-2005

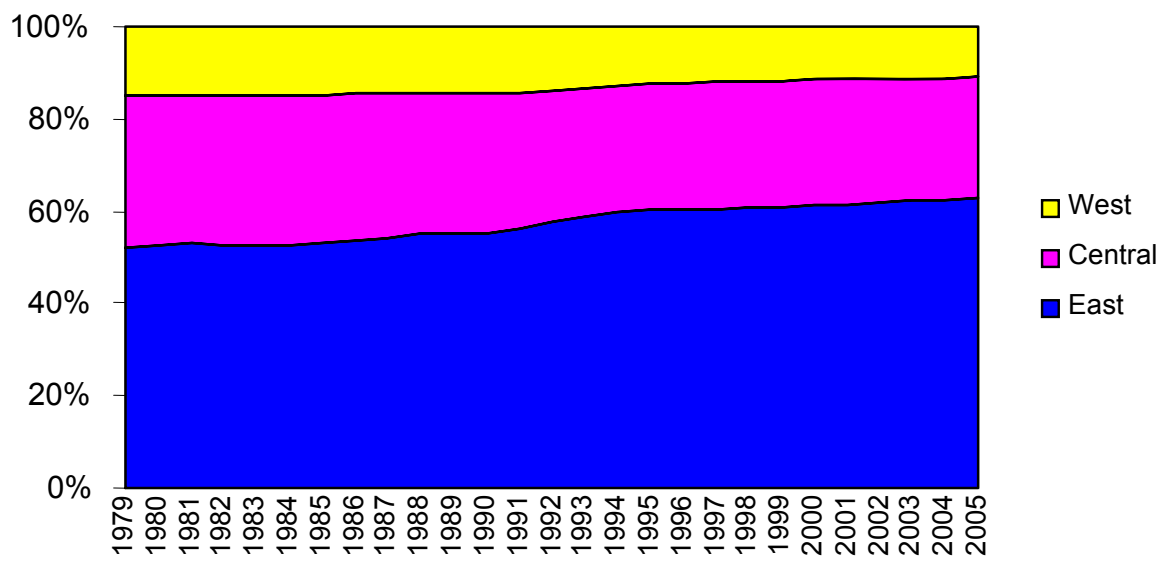

Note: Real GDP measured in 1990s prices.

Source: NBS (1999) and (NBS-CSY) various issues.

Figure 3

Shares of real FDI by region, 1979-2005

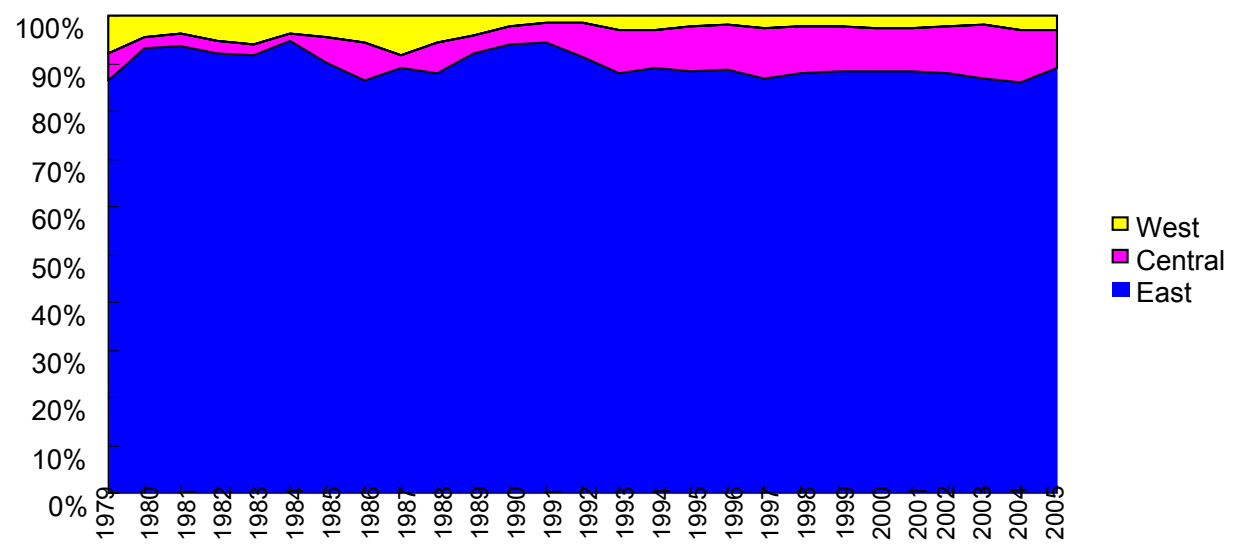

Note: Real FDI is actually used FDI measured in 1990s prices.

Source: NBS (1999) and (NBS-CSY) various issues. 
Several reasons explain this geographic polarization of FDI. First of all, early reform was focused on the eastern provinces. Guangdong, Fujian, 14 coastal cities, Hainan and Pudong were gradually opened to foreign investors in terms of designated special economic zones, development zones, economic and technology development zones. All of them were given preferential policies to attract foreign capital and promote exports. Since the mid-1980s, the opening up policy has been extended northward. Only in the early 1990s were inland cities and border areas encouraged to open up. In the late 1990s, the Chinese government announced a western development programme aiming at restoring a more balanced regional development and decided to apply preferential policies to attract more FDI into the inland areas. The western development programme may have helped the west to accelerate its economic growth but failed to reduce its growth and foreign investment gaps with the eastern region.

In fact, preferential policies have been only one of the advantages that the east region offered to foreign investors. It also has better economic endowments which give it comparative advantages over the central and west regions: geographic proximity to international markets, better transport infrastructures, and more skilled labour. Furthermore, many coastal provinces have advanced rapidly in economic liberalization, have developed a dynamic non-state sector, and have thus provided a more favourable environment to foreign investors. Finally, as they have recorded higher economic growth, they also have provided foreign business with larger and rapidly expanding markets.

\section{Empirical models and data}

Will the west/central regions of China remain poor for the next century? Will the east still be the rich region in the following decades? Is the degree of economic disparity between China's regions increasing or falling over time? The concepts of $\sigma$-convergence, absolute and conditional $\beta$-convergence are discussed in this section to answer these important questions.

\section{$3.1 \sigma$-convergence}

The concept of $\sigma$-convergence can be defined as 'a group of economies are converging in the sense of $\sigma$ if the dispersion of their real per capita GDP levels tends to decrease over time' (Sala-i-Martin 1996: 1020). It is used to reflect the static disparities in per capita income. It can be regarded as evidence of $\sigma$-convergence between China's regions if regional income disparity declines over time. Commonly, it is measured by the coefficient of variation $(\mathrm{CV})$ which is the ratio of standard deviation to the mean. ${ }^{2}$

$$
C V=\frac{\sqrt{\frac{\sum\left(y_{i}-\bar{y}\right)^{2}}{n}}}{\bar{y}}
$$

where $y_{i}$ is real GDP per capita in region $i$ and $\bar{y}$ is the mean value.

2 Yao and Zhang (2001b) measure $\sigma$-convergence by the interprovincial Gini coefficient and the time standard deviation of $\log$ (GDP per capita). 
Given a contraction in $\mathrm{CV}$, we can say that the economies under consideration have experienced $\sigma$-convergence with reduced difference in their income levels. A higher value of $\mathrm{CV}$ indicates a more serious income disparity, and vice versa. The CV not only quantifies the income inequality problem but also measures the development of income gap between different economies. It has been widely used in the literature, such as Lyons (1991), Tsui (1996), Chen and Fleisher (1996), Raiser (1998), Zheng, Xu and Tang (2000), Xu and Zou (2000), Wu (2002) and Chang (2002). The CV index in these studies is calculated by the net material product, national income, or per capita GDP in nominal or real value to assess the evolution of regional income inequality in the preand post-reform periods.

Figure 4 presents the indices of $\mathrm{CV}$ at national and regional levels based on real per capita GDP. The income gap in the whole country during 1979-2003 experienced three phases: declining from 0.6924 to 0.6028 in $1979-89$, expanding to 0.6680 in 1998 , and declining again to 0.6180 in 2003 . This pattern reflects the process of economic reform and policies adopted during the past decades. At the beginning, the whole country benefited from economic reform, achieving impressive economic development. Some initially poorer economies took advantage of their backwardness and performed more rapidly than some initially richer ones, leading to a contraction of income gap for the country. In the second stage, the coastal provinces benefited greatly from the preferential policies granted by the central government. For instance, the eastern region was allowed to adopt a market system and to open its door to foreign investors before the rest of the country. Consequently, FDI largely flowed into the coastal cities, greatly accelerating export activities and local development. As a result, income disparity between the coastal and inland regions began to deteriorate in this period. In the three stage, the income gap appeared to have declined, thanks to the government's western development programme and the rebuilding programme of the northeast region (Zheng, $\mathrm{Xu}$ and Tang 2000; Chang 2002). However, the reduction in the CV in the third phase may be too little to be statistically significant and whether the income inequality among the Chinese regions really declined has to be tested using a more robust parametric approach as is discussed later in this paper.

Figure 4

Coefficient of variation in comparison

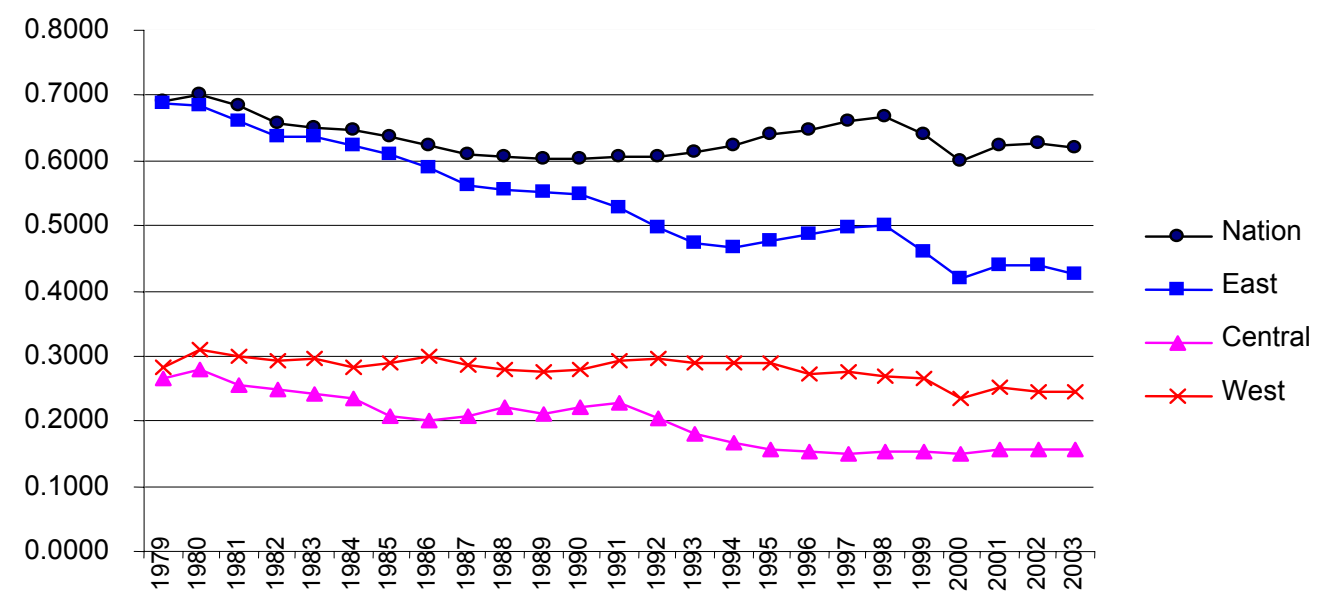

Note: $\quad$ CV calculated according to Equation 1.

Source: NBS (1999) and (NBS-CSY) various issues. 
At the regional level, three macro-geographical regions (east, central, and west) are found to have different CVs in terms of their values and trends. The east had the highest value of $\mathrm{CV}$ and the central the lowest, meaning that income gaps were highest within the east and lowest within the central. The trends of CVs have a clear and declining tendency in all regions, especially in the east. Oscillation in regional CVs implies that intraregional inequality declined, especially among the eastern provinces. The sluggishness of the national $\mathrm{CV}$ and the reduced regional $\mathrm{CVs}$ indicate that interregional inequality must have risen. This is consistent with the conclusion drawn by Yao and Zhang (2001b) on the formation of three geo-economic clubs in China under economic reforms.

\section{$3.2 \beta$-convergence}

According to Sala-i-Martin (1996b: 1020) 'there is absolute $\beta$-convergence if poor economies tend to grow faster than rich ones'. In other words, this is to test if an initially lower-income group has higher speed of income growth, and convergence is a process in which the poorer economies catch up with the richer ones. This argument is based on the neoclassical model, which predicts that initially poor countries will grow faster than initially rich ones if the only difference across countries lies in their initial levels of capital (Solow 1956; Sala-i-Martin 1996). However, in the real world, economies may differ in other respects such as technological progress, population growth, investment, infrastructure, and political stability. If these differences are considered, the neoclassical models will predict that the growth of an economy will be positively related to the distance that separates it from its own steady state. This is the concept known in the classical literature as conditional $\beta$-convergence (Sala-i-Martin 1996; Yao and Zhang 2001b).

In absolute convergence, initial income level is the only factor of concern and the catching-up process will take place if the initially poorer economies have higher growth than the initially richer ones. To examine absolute $\beta$-convergence, the simple regression that was suggested in Baumol (1986) and applied in Chen and Fleisher (1996), Jian, Sachs and Warner (1996), Gundlach (1997), Raiser (1998), Zhang (2001) and Yao and Zhang (2001b) will be adopted in this research, to regress the growth rate of real GDP (RGDP) per capita against the beginning period's level of RGDP per capita. The regression function is specified as:

$\operatorname{Ln}\left(y_{i t}\right)-\operatorname{Ln}\left(y_{i 0}\right)=\alpha+\beta \operatorname{Ln}\left(y_{i 0}\right)+\varepsilon_{i t}$

and $\beta=-\left(1-e^{-\lambda t}\right)$

Where $y_{i t}, y_{i 0}$ denote, respectively, per capita RGDP of the ending and beginning periods, respectively in the $i$ th economy, $t$ is the timespan. A statistically significant and negative $\beta$ suggests absolute income convergence. It implies that an initially poorer economy, such as the remote provinces in western China, can take advantages of its backwardness to achieve a higher growth rate so as to catch up with the initially richer provinces such as the east region. On the contrary, if $\beta \geq 0$, the data exhibit no absolute $\beta$-convergence. It may even show an absolute $\beta$-divergence since an economy with higher initial income tends to grow faster; then the initially richer economies will become even richer, while the initially poorer economies will become even poorer in the group. The value of $\lambda$ is the pace of income convergence (or divergence). 
As for conditional convergence, income convergence and the catching-up process can only be initiated given the presence of additional control factors, such as investment ratio, population growth, openness, FDI ratio, human capital and infrastructure, etc. If absolute $\beta$-convergence is observed, then conditional $\beta$-convergence is also implied. In conditional $\beta$-convergence, the above-mentioned growth related factors determine the steady state income level of an economy and if an economy is far from its steady state income level, and it will tend to have a higher speed of economic growth until it arrives at its steady state. However, in the process of conditional $\beta$-convergence, the initially poorer economies will have a tendency to move just towards its own steady-state income level.

Taking into account the investment ratio and the effective population growth rate, the estimation equation of conditional convergence can be written as:

$$
\begin{aligned}
\operatorname{Ln}\left(y_{t}\right)-\operatorname{Ln}\left(y_{0}\right)= & \left(1-e^{-\lambda t}\right) \frac{\alpha}{1-\alpha-\beta} \operatorname{Ln}(s)-\left(1-e^{-\lambda t}\right) \frac{\alpha+\beta}{1-\alpha-\beta} \operatorname{Ln}(n+g+\delta) \\
& -\left(1-e^{-\lambda t}\right) \operatorname{Ln}\left(y_{0}\right)
\end{aligned}
$$

which was derived from:

$$
\operatorname{Ln}\left(y_{t}\right)-\operatorname{Ln}\left(y_{0}\right)=\left(1-e^{-\lambda t}\right) \operatorname{Ln}\left(y^{*}\right)-\left(1-e^{-\lambda t}\right) \operatorname{Ln}\left(y_{0}\right)
$$

and the steady state level of income per capita, $y^{*}$, was defined as:

$$
\frac{d \operatorname{Ln}\left(y_{t}\right)}{d t}=\lambda\left[\operatorname{Ln}\left(y^{*}\right)-\operatorname{Ln}\left(y_{t}\right)\right], \text { where } \lambda=(n+g+\delta)(1-\alpha-\beta)
$$

where $y_{t}$ denotes real income per capita and $y_{0}$ the value in the initial period, $n$ population growth, $g$ a rate of technological progress, $\delta$ rate of capital depreciation. $\alpha$ is the capital share in income and $\beta$ is the labour share. $s$ is the investment in physical capital as a share in GDP, $\lambda$ is the rate of convergence. According to Mankiw, Romer, and Weil (1992), this augmented Solow growth model specifies that the growth of income is a function of the determinants of the ultimate steady state and the initial level of income. 3

This model argues that the income per capita in an economy will converge to the economy's own steady-state level, which is determined by its own endowments, such as capital accumulation, population growth and depreciation, and so on. The income levels between different economies, however, may not necessarily approach to a similar level over time. Specifications similar to the above-mentioned model could also be found in Gundlach (1997), Raiser (1998), ${ }^{4}$ Zhang (2001) and Yao and Zhang (2001a, 2001b). In assessing the growth pattern of China, Yao and Zhang (2001b) incorporate some

3 Mankiw, Romer, and Weil (1992: 423).

4 In Raiser (1998), the ratio of non-state enterprises output to industrial production and light industry output to industrial production have been inserted into the estimation of conditional convergence to show how the open door policy, the market liberalization and the structural change have contributed to the growth and income convergence of mainland China. 
additional factors, such as the international trade to GDP ratio, transportation measured by the equivalent length of highways and regional dummies in their estimation.

Since FDI is considered to be one of the engines to economic growth in China (Yao and Wei 2007), this research applies similar specification by adding FDI to examine conditional $\beta$-convergence at national and regional levels. Regressions are run on both cross-sectional and pooled basis to estimate the pace of unconditional or conditional $\beta$-convergence, which is the speed at which different economies return to their respective steady state output levels. The estimations also aim at addressing the growth discipline of these economies, as well as the contributions of different factors, such as investment ratio, population growth, openness ratio, FDI ratio, human capital, and transportation, 5 to the growth pace and speed of income convergence. The functional form of the estimation equation is specified as:

$$
\begin{aligned}
\operatorname{Ln} Y_{i t}-\operatorname{Ln} Y_{i 0}= & \text { Constant }+\left(1-e^{-\lambda t}\right) \operatorname{Ln} Y_{i 0}+\gamma_{1} \operatorname{Ln}(s)_{i}+\gamma_{2} \operatorname{Ln}(n+g+\delta)_{i}+\gamma_{3} \operatorname{Ln}(F D I)_{i} \\
& +\gamma_{4} \operatorname{Ln}(\text { Export })_{i}+\gamma_{5} \operatorname{Ln}(H E P)_{i}+\operatorname{Ln}(\operatorname{Tran})_{i}+\varepsilon_{i}
\end{aligned}
$$

This specification is derived from the Solow growth model with a Cobb-Douglas production function as the basis. Where $y_{i t}, y_{i 0}$ denote, respectively, per capita RGDP of the ending and beginning periods in the $i$ th economy, the investment ratio $s$ is calculated as the share of investment as a proportion of GDP. The population growth $n$ is calculated as the annual growth rate of the year-end population. We set $(g+\delta)$ equal to 0.05 and assume this value to be the same for all provinces and all years. 6 FDI is defined as the ratio of actually used FDI to total investment to avoid multi-collinearity and double accounting. Export is also defined as the ratio of total value of exports to GDP instead of the absolute value of export to avoid the problem of multi-collinearity. HEP, or human capital, can be defined in different ways, the ratio of the number of students enrolled in higher education over population, the ratio of the number of students enrolled in secondary education over population, the ratio of the number of students enrolled in higher education to the number of students enrolled in secondary education, or investments in education, science, health care and cultural activities. This paper chooses the ratio of the number of students enrolled to higher education over population. Data for GDP are gross domestic product. All the variables are calculated in 1990 constant prices.

The values of exports and FDI are provided in US dollars in the official statistics. Since they are measured in US dollars, most economic analysts do not bother to deflate the values in current prices into values in constant prices (e.g., Liu et al. 1997; Liu 2000). It is important to conduct an appropriate deflation. One relevant deflator is the US consumer price index. The values of trade and FDI in nominal dollars are deflated by this index. The deflated values are converted into equivalent values in RMB by multiplying the value with the official exchange rate in 1990 (US\$1=RBM4.784). Since

5 Yao and Wei (2007) find that the factors of FDI ratio, export ratio, human capital, and transportation have been proved to present significant impact on the GDP growth in China at both national and regional levels.

6 Yao and Zhang (2001b: 174). 
all the other variables in the model are measured in RBM, it is useful to change these two variables in RBM as well.

Tran, or transportation, is measured as the equivalent mileage of railways, highways, and waterways per $1,000 \mathrm{~km}^{2}$. Highways are the dominant means of transportation in terms of distance. The ratios of the lengths of railways, highways, and waterways are $1.00 / 16.84 / 1.90$ at the national level. The simplest way to measure transportation is to add the total lengths of these three different means of transportation (e.g., Liu et al. 1997; Fleisher and Chen 1997). However, the transportation capacity of one mile of railway is different from that of one mile of highway or waterway, and as a result, it is necessary to convert railways and waterways into equivalent highways. The conversion ratios are derived from the volumes of transport per mile by each of the three means of transportation. At national average, the conversion ratios are 4.27/1.00/1.06. In other words, railways are multiplied by 4.27 and waterways by 1.06 to derive their equivalent lengths of highway. This method of conversion may not be perfect as the relative capacity of the different means of transportation may not be the same in different provinces. However, any possible conversion errors may be small because highways account for a predominant proportion of the total transportation volume (Yao and Wei 2007).

Data are based on a panel of 29 provinces and municipalities (Tibet is excluded and Chongqing is merged with Sichuan) for the period 1979-2003. Two principal data sources are available: China Statistical Data 50 Years 1949-98 (NBS 1999) and China Statistical Yearbook (NBS-CSY, various years 1999-2004).

The above-mentioned $\beta$-convergence test is employed to examine whether and at what speed the per capita income level of China and its regions are converging after controlling their growth potential, or if the initially poorer inland China is able to grow at a higher speed than the initially richer coastal east. To address the issue of absolute $\beta$-convergence among regions, a simple estimation is employed on the growth rate of per capita RGDP at the beginning year's per capita RGDP. The intention is to assess if the growth rate of these economies is negatively related to its initial income level. Given a negative and statistically significant estimated coefficient for the initial income level, it is possible to conclude that the initially poorer economy is able to achieve a higher growth rate which enables it to catch up with the initially richer economy, and $\beta$-convergence is taking place in an absolute manner.

Both cross-section and panel data approaches are employed in this section for comparison. In the panel regression, the sampling period (1979-2003) can be divided into six time spans: 1979-83, 1983-87, 1987-91, 1991-95, 1995-99, 1999-2003. When $t=1983$, for example, $t-1=1978$, all the related variables to each province are the averages over 1978-83. Data for the other periods are derived in the same way.

\section{Estimation results}

In the estimations, the Chinese provinces are divided into three regions: east (coastal), central, and west (see footnote 1). Income convergence is analysed for each region and for the whole country. In addition, a pair-wise analysis is also conducted to examine the 
convergence or divergence for the following pairs of regions: east-central, east-west, and central-west.

\subsection{Estimation results of $\beta$-convergence at national level}

\section{Absolute income convergence}

Based on Equation (2), only $\operatorname{Ln}\left(y_{0}\right)$ is included on the right-hand side to test for absolute convergence. As reported in the upper panel of column 2 in Table 2, there is no evidence of absolute $\beta$-convergence. The estimated coefficient of the initial income during 1979-2003 is statistically insignificant, implying that the initially poorer Chinese provinces do not have higher growth than the initially richer ones and thus fail to catch up. The initially poorer provinces could have benefited by the reforms enabling them to grow faster than before. However, the coastal provinces might be able to continuously derive disproportionately greater benefits from the reforms after 1992 as the central government encouraged them to speed up the pace of reform and development with more open policies in terms of FDI and exports. Their speed of growth might then outperform the others. Hence, the process of absolute convergence has not been noted in the entire post-reform period. This finding is rather similar to those offered by Chen and Fleisher (1996) and Jian, Sachs, and Warner (1996) in which the former show NO absolute $\beta$-convergence in both the pre- and post-reform periods, while the latter suggested a mixed result with no clear absolute $\beta$-convergence.

An east dummy is introduced in the analysis to capture the impact of the preferential policies favouring the east region. As shown in the second panel of column 2 in Table 2, income convergence is observed and the adjusted $\mathrm{R}^{2}$ increases significantly compared with that in the upper panel. It shows that economic reform and the resulting higher growth have brought about conditional $\beta$-convergence, particularly to the eastern region. The speed of convergence is 1.67 per cent in the cross-section regression. This may imply that some of the initially poorer economies in the east, such as Guangdong and Fujian, have experienced a rapid growth after economic reform which enabled them to catch up with the other initially richer economies in the country. Furthermore, the east dummy is strongly significant. It shows that the east region has its own income growth pattern which is different from the other regions of the country. This specific growth discipline can very much be explained by the open door policies and the preferential treatment which were firstly introduced in the coastal region with an intention to promote trade and to attract foreign investment.

Apart from the cross-sectional analysis, the panel data approach has also been advocated to address the issue of absolute $\beta$-convergence. Such pooled analysis may help to resolve the possible significance problem which is caused by the shortening of observations. As indicated in the first half of column 3 in Table 2, like its cross-section counterpart, no evidence of absolute $\beta$-convergence can be found. The estimated coefficient on the initial income level is even positive although it is insignificant. The adjusted $\mathrm{R}^{2}$ is very small. It means that Chinese provinces were not able to move their income levels towards the national mean, and the initially poorer regions failed to have a higher growth rate after economic reform. In other words, the west or/and central regions failed to catch up with the east. Dissimilar to the cross-section regression, the introduction of an east dummy could neither revise nor improve the estimation results as the estimated coefficient of the initial income level is still insignificant. However, the 
east dummy is statistically significant and raises the adjusted $\mathrm{R}^{2}$ although it is still small. This finding indicates that the initial income level and east dummy are far from explaining the dependent variable.

Table 3 compares our estimated results with those in the literature for different datasets. Our cross-section regression for the period 1979-2003, like the regression by Yao and Zhang (2001b) for cross-section analysis as well as Chen and Fleisher (1996) for 1978-93, shows evidence of convergence, but the test statistics are not significant. In contrast, like the cross-section regression by Chen and Fleisher for a longer time period 1952-92, our panel data regression shows evidence of divergence, although it is also insignificant. The panel data regression by Yao and Zhang (2001b), however, shows a clear evidence of divergence because the value of $\lambda$ is negative and significant. This evidence contrasts sharply with that presented by Gundlach (1997) and Raiser (1998).

According to the neoclassical model, the initially poor countries will grow faster than the initial rich ones if the only difference across countries lies in their initial level of capital (Solow 1956; Swan 1956).

However, in the literature, many studies find no evidence of absolute convergence for countries with different institutions, preferences, and production technologies. Sala-i-Martin (1996), by estimating the data for 110 countries during 1960-90, shows significant divergence rather than convergence and the speed of divergence was 0.4 per cent per annum. This finding implies that economies may differ in other respects in the real world, such as population growth, saving behaviour, technology, and political stability. If these differences are considered, the neoclassical model predicts that the growth of an economy will be positively related to the distance that separates it from its own steady state. This is the concept of conditional convergence and focus of analysis in the next section.

Table 2

Basic convergence regressions analysis at national level, 1979-2003

\begin{tabular}{|c|c|c|c|}
\hline \multirow{2}{*}{$\frac{\text { Method }}{\text { Constant }}$} & Cross-section analysis & \multicolumn{2}{|c|}{ Panel data analysis } \\
\hline & $(28.372)^{* *}$ & 0.328 & $(32.751)^{* *}$ \\
\hline $\operatorname{Ln} Y_{i 0}$ & $(-0.557)$ & 0.018 & $(1.582)$ \\
\hline Implied $\lambda$ & 0.0029 & \multicolumn{2}{|c|}{-0.0007} \\
\hline Adjusted $\mathrm{R}^{2}$ & 0.025 & \multicolumn{2}{|c|}{0.009} \\
\hline \multicolumn{4}{|c|}{ With east dummy } \\
\hline Constant & $(21.853)^{* *}$ & 0.313 & $(28.296)^{* *}$ \\
\hline $\operatorname{Ln} Y_{i 0}$ & $(-3.258)^{\star \star}$ & 0.003 & $(0.239)$ \\
\hline East dummy & $(5.032)^{\star *}$ & 0.054 & $(2.969)^{* *}$ \\
\hline Implied $\lambda$ & 0.0167 & \multicolumn{2}{|c|}{-0.0001} \\
\hline Adjusted $\mathrm{R}^{2}$ & 0.461 & \multicolumn{2}{|c|}{0.052} \\
\hline
\end{tabular}

Notes: Estimated equation: $\operatorname{Ln} Y_{i t}-\operatorname{Ln} Y_{i 0}=$ Cons $\tan t+\left(1-e^{-\lambda t}\right) \operatorname{Ln} Y_{i 0}+\varepsilon_{i}$.

t-statistics in parentheses.

${ }^{* *}$ and ${ }^{*}$ indicate statistical significance at $1 \%$ and $5 \%$ levels, respectively. $Y_{i t}$ and $Y_{i 0}$ are real GDP per capita in the ith province in 2003 and 1979 respectively in cross-section analysis. In panel data analysis, they are real GDP per capita in each ending year and beginning year of six time spans. Real GDP is calculated at constant 1990 prices. East dummy takes the value of 1 for an eastern region and 0 otherwise.

Source: NBS (1999) and (NBS-CSY) various issues. 
Table 3

Speed of convergence and divergence $(\lambda)$ for different datasets

\begin{tabular}{|c|c|c|c|}
\hline \multirow[t]{2}{*}{ Dataset } & \multicolumn{3}{|c|}{ Cross-section regression } \\
\hline & $\lambda$ & t value & $\mathrm{R}^{2}$ \\
\hline \multicolumn{4}{|l|}{ Our estimates } \\
\hline China, 29 provinces (1979-2003) (cross-section data) & 0.0029 & 0.557 & 0.025 \\
\hline China, 29 provinces (1979-2003) (panel data) & -0.0007 & 1.582 & 0.009 \\
\hline \multicolumn{4}{|l|}{ Yao and Zhang (2001b) } \\
\hline China, 30 provinces (1978-95) (cross-section data) & 0.009 & 1.10 & 0.040 \\
\hline China, 30 provinces (1979-95) (panel data) & -0.0025 & 1.89 & 0.029 \\
\hline \multicolumn{4}{|l|}{ Chen and Fleisher (1996: table 1) } \\
\hline China, 25 provinces (1952-92) (cross-section data) & -0.005 & 1.47 & 0.046 \\
\hline China, 25 provinces (1978-93) (cross-section data) & 0.009 & 1.54 & 0.054 \\
\hline \multicolumn{4}{|l|}{ Raiser (1998: table 2) } \\
\hline China, 28 provinces (1978-92) (cross-section data) & 0.0255 & 2.74 & 0.287 \\
\hline \multicolumn{4}{|l|}{ Gundlach (1997: 426) } \\
\hline China, 29 provinces (1978-89) (cross-section data) & 0.0220 & 3.14 & 0.280 \\
\hline \multicolumn{4}{|l|}{ Sala-i-Martin (1996) } \\
\hline World, 110 countries (1960-90) & -0.004 & 2.00 & 0.4 \\
\hline OECD countries (1960-90) & 0.014 & 4.33 & 0.48 \\
\hline USA, 48 states $(1980-90)$ & 0.021 & 7.00 & 0.89 \\
\hline Germany, 11 regions (1950-90) & 0.014 & 2.33 & 0.56 \\
\hline UK, 11 regions $(1950-90)$ & 0.020 & 2.50 & 0.62 \\
\hline
\end{tabular}

Notes and sources:

The values in column 3 are asymptotic $t$-value for the convergence speed parameter $\lambda$. If the value $\lambda$ is positive, it indicates convergence, or vice versa.

Yao and Zhang (2001b) use real GDP per working-age person instead of real per capita GDP. Furthermore, they had data for 30 provinces. And their results are most similar to ours.

Chen and Fleisher (1996) use real per capita national income, instead of real per capita GDP in 1952-92 and real per capita GDP in 1978-93. At the time of their writing, GDP data were not available before 1988 from official statistics. In addition, they did not have data for five provinces, Guangxi, Jilin, Hainan, Qianghai, and Tibet. Despite the obvious caveats in the data sets, their results are not fundamentally different from ours.

Raiser (1998) takes data from a number of different sources, including his personal calculations.

\section{Conditional income convergence}

If the initially poorer economies cannot grow faster than the initially richer ones, then they should have failed to catch up and reduce their income gap with the initially richer economies. Nevertheless, they may still be able to move their income levels to their respective steady states, which are determined by some growth related factors. Based on this belief, the conditional income convergence test is performed to estimate if the catching-up and convergence process takes place after imposing controls on the growth potential of these economies, despite no tendency of absolute income convergence.

In Equation (3), only two basic factors, investment ratio and effective population growth rate, plus the initial income are added to the right hand side of regression. As indicated in Table 4, in the cross-section estimations, these two factors appeared to be statistically insignificant with wrong signs and they are able neither to improve nor revise the results of its absolute manner in Table 2. There is no evidence of conditional convergence and 
the estimated coefficient of the initial income level is insignificantly positive. Furthermore, the adjusted $\mathrm{R}^{2}$ is still small, implying poor goodness-of-fit in the regression. In other words, there is no evidence of conditional income convergence between the Chinese provinces and the pace of income growth for the period 1979-2003 might be independent of investment ratio and effective population growth. This result matches some of the findings in Gundlach (1997), Yao and Zhang (2001a) and Jones, Li and Owen (2003). When the east dummy is adopted in the estimations, the explanatory power of these two additional variables is still poor. But the east dummy is statistically significant and has contributed to bringing about negative significance at 5 per cent level on the initial income. In addition, the adjusted $\mathrm{R}^{2}$ increases to 0.433 , and the speed of convergence rises to 1.36 per cent. This result reveals that the process of conditional convergence is almost independent of the investment ratio and effective population growth.

The results of panel data regressions are presented in the last column of Table 4 . In general, the significance of the estimation results on convergence has obviously improved compared with either its absolute manner or cross-sectional counterpart. The two explanatory variables now have right signs and the investment ratio is significant at 5 per cent level. Besides, they have contributed to changing the estimated coefficient of the initial income to be negative although it is insignificant. After the east dummy addressing, the estimation results are striking. There is strong evidence of conditional income convergence in 1979-2003 and all the explanatory variables become strongly significant in proper signs. The estimated values of adjusted $\mathrm{R}^{2}$ and the speed of convergence have also improved. This confirms that the region-specific effects must be correlated with the included variables. As explained above, investment ratio and effective population growth rate are just two of the factors that may affect growth. A high investment ratio and a low effective population growth rate may be necessary but not sufficient for achieving higher growth. Therefore, they are not satisfactory explanatory variables and have failed to explain the growth discipline of the Chinese provinces. This suggests that some important explanatory variables other than the investment ratio and population growth are missing from the regressions.

The other estimation on the issue of conditional convergence is based on Equation (6), including FDI ratio, export ratio, human capital, and transportation apart from the two additional variables measured above. As shown in Table 5, conditional convergence is found in both cross-section and panel data approaches. The estimation in the panel data analysis presents much more significance. All the variables except for human capital and transportation are statistically significant in their expected signs. However, in the cross-section analysis, only export ratio is observed significant for the conditional convergence. However, the speed of convergence as well as the adjusted $\mathrm{R}^{2}$ have experienced remarkable improvements. The speed of convergence is as high as 6.06 per cent per year and $\mathrm{R}^{2}$ increases to 0.518 from a negligible value in the previous estimations, implying a strong goodness-of-fit in this regression. Besides, investment ratio and effective population growth rate have the correct signs. In addition, FDI ratio becomes significant when export ratio is ignored from the regression although there is no evidence of conditional convergence. This implies that the explanatory power of FDI and export are diluted somewhat when they are employed together. The estimation results have not improved nor revised when the east dummy is inserted. However, not only the estimation value but also the significance level of initial income increase. 
Table 4

Conditional convergence regressions at national level, 1979-2003: by adding $L n(s)$ and $L n(n+g+\delta)$

\begin{tabular}{|c|c|c|}
\hline Method & Cross-section analysis & Panel data analysis \\
\hline Constant & $(0.974)$ & $-0.472(-2.022)^{*}$ \\
\hline $\operatorname{Ln} Y_{\text {io }}$ & $0.031 \quad(0.216)$ & $-0.010 \quad(-0.687)$ \\
\hline $\operatorname{Ln}(s)$ & $-0.065 \quad(-1.337)$ & $0.072(2.090)^{*}$ \\
\hline $\operatorname{L} n(n+g+\delta)$ & $0.919 \quad(0.596)$ & $-0.325 \quad(-0.325)$ \\
\hline Implied $\lambda$ & -0.0012 & 0.0004 \\
\hline Adjusted $\mathrm{R}^{2}$ & 0.022 & 0.086 \\
\hline \multicolumn{3}{|c|}{ With east dummy } \\
\hline Constant & $(0.696)$ & $-0.641(-2.870)^{* *}$ \\
\hline $\operatorname{Ln} Y_{0 \mathrm{i}}$ & $-0.289(-2.278)^{*}$ & $-0.046(-2.989)^{* *}$ \\
\hline $\operatorname{Ln}(\mathrm{s})$ & $-0.262 \quad(-0.708)$ & $0.120(3.501)^{\star *}$ \\
\hline $\operatorname{Ln}(n+g+\delta)$ & $0.227 \quad(0.196)$ & $-0.401(-4.862)^{* *}$ \\
\hline East dummy & $0.487 \quad(4.588)^{\star *}$ & $0.083(4.644)^{* *}$ \\
\hline Implied $\lambda$ & 0.0136 & 0.0019 \\
\hline Adjusted $\mathrm{R}^{2}$ & 0.433 & 0.185 \\
\hline
\end{tabular}

Notes: Estimated equation: $\operatorname{Ln} Y_{i t}-\operatorname{Ln} Y_{i 0}=\operatorname{Cons} \tan t+\left(1-e^{-\lambda t}\right) \operatorname{Ln} Y_{i 0}+\gamma_{1} \operatorname{Ln}(s)_{i}+\gamma_{2} \operatorname{Ln}(n+g+\delta)_{i}+\varepsilon_{i}$. t-statistics in parentheses. ${ }^{* *}$ and * indicate statistical significance at $1 \%$ and $5 \%$ level respectively. All the values are measured in 1990 prices. $Y_{i t}$ and $Y_{i 0}$ are real GDP per capita in ith province in 2003 and 1979 respectively in cross-section analysis. In panel data analysis, they are real GDP per capita in each ending year and beginning year of six time spans. Investment ratio $s$ equals investment/ real GDP, population growth rate $n$ is the annual growth rate of the year-end population. $(g+\delta)$ equal 0.05 all the time. East dummy takes the value of 1 for an eastern region and 0 otherwise.

Source: NBS (1999) and (NBS-CSY) various issues.

Furthermore, the speed of convergence improves 0.5 per cent a year, although the significance of export and FDI ratios are slightly reduced. It indicates that these three variables may have been diluted by other factors because of multi-collinearity which is not easy to control in the regression model. In the panel data regression, all the variables expect for human capital and transportation are significant. Like its cross-section counterpart, the speed of convergence and the adjusted $\mathrm{R}^{2}$ both improve compared with Table 4. East dummy has the same effects on the results of both methods, i.e., panel data and cross-section.

To find out if the insignificant variables human capital and transportation have contributed to accelerating China's provinces to approach their own steady-state income levels, we run an auxiliary regression excluding some other factors. When we just employ human capital and the east dummy plus initial income in the regression, strong evidence of conditional convergence is detected at the 1 per cent level and human capital shows positive significance at the 5 per cent level. When only transportation is added with investment ratio and population growth on the right-hand side, the results show conditional convergence with strong significance and correct signs of all the three explanatory variables. These re-estimations imply that human capital and transportation have an impact on regional convergence, but their influences are not as important as other factors. Their explanatory power might be partly diluted when they go with the other more important factors such as FDI and export. This result indicates that the difference in investment, population growth rate, exports, and FDI development could be the main causes of heterogeneous economic performance of the country. Only after controlling these factors, are the different regions able to push their income levels towards their own steady states. 
Table 5

Conditional convergence regressions at national level, 1979-2003

by adding $L n(s), L n(n+g+\delta)$, FDI, export, human capital and transportation

\begin{tabular}{|c|c|c|c|c|}
\hline \multirow{2}{*}{$\frac{\text { Method }}{\text { Constant }}$} & \multicolumn{2}{|c|}{ Cross-section analysis } & \multicolumn{2}{|c|}{ Panel data analysis } \\
\hline & -4.190 & $(-1.309)$ & -0.783 & $(-3.393)^{* *}$ \\
\hline $\operatorname{Ln} Y_{i o}$ & -0.780 & $(-2.829)^{\star *}$ & -0.098 & $(-3.867)^{* *}$ \\
\hline $\operatorname{Ln}(s)$ & 0.380 & $(0.832)$ & 0.160 & $(4.638)^{* *}$ \\
\hline $\operatorname{Ln}(n+g+\delta)$ & -2.034 & $(-1.648)$ & -0.438 & $(-5.380)^{\star *}$ \\
\hline $\operatorname{Ln}(F D I R)$ & 0.029 & $(0.425)$ & 0.034 & $(5.885)^{\star *}$ \\
\hline $\operatorname{Ln}(\operatorname{ExpR})$ & 0.401 & $(3.376)^{\star *}$ & 0.036 & $(3.298)^{\star *}$ \\
\hline $\operatorname{Ln}(H E P)$ & 0.091 & $(0.566)$ & -0.023 & $(-1.257)$ \\
\hline $\operatorname{Ln}($ Tran $)$ & 0.021 & $(0.259)$ & 0.007 & $(0.636)$ \\
\hline Implied $\lambda$ & 0.0 & 606 & 0.0 & 041 \\
\hline Adjusted $\mathrm{R}^{2}$ & 0.5 & 18 & 0.3 & \\
\hline \multicolumn{5}{|c|}{ With east dummy } \\
\hline Constant & -2.732 & $(-0.746)$ & -0.740 & $(-3.091)^{\star *}$ \\
\hline $\operatorname{Ln} Y_{0 \mathrm{i}}$ & -0.804 & $(-2.881)^{* *}$ & -0.099 & $(-3.896)^{* *}$ \\
\hline $\operatorname{Ln}(s)$ & 0.204 & $(0.404)$ & 0.158 & $(4.554)^{* *}$ \\
\hline $\operatorname{Ln}(n+g+\delta)$ & -1.523 & $(-1.099)$ & -0.430 & $(-5.218)^{* *}$ \\
\hline $\operatorname{Ln}(F D I R)$ & 0.005 & $(0.069)$ & 0.033 & $(5.767)^{\star \star}$ \\
\hline $\operatorname{Ln}(\operatorname{ExpR})$ & 0.337 & $(2.377)^{*}$ & 0.030 & $(2.115)^{*}$ \\
\hline $\operatorname{Ln}(H E P)$ & 0.157 & $(0.872)$ & -0.020 & $(-1.036)$ \\
\hline $\operatorname{Ln}(\operatorname{Tran})$ & 0.003 & $(0.035)$ & 0.005 & $(0.426)$ \\
\hline East dummy & 0.169 & $(0.838)$ & 0.016 & $(0.692)$ \\
\hline Implied $\lambda$ & & 0652 & & 0042 \\
\hline Adjusted $\mathrm{R}^{2}$ & & 511 & & 345 \\
\hline
\end{tabular}

Notes: Estimated equation:

$\operatorname{Ln} Y_{i t}-\operatorname{Ln} Y_{i 0}=$ Cons $\tan t+\left(1-e^{-\lambda t}\right) \operatorname{Ln} Y_{i 0}+\gamma_{1} \operatorname{Ln}(s)_{i}+\gamma_{2} \operatorname{Ln}(n+g+\delta)_{i}+\gamma_{3} \operatorname{Ln}(F D I)_{i}$

$+\gamma_{4} \operatorname{Ln}(\text { Export })_{i}+\gamma_{5} \operatorname{Ln}(\text { HEP })_{i}+\gamma_{6} \operatorname{Ln}(\operatorname{Tran})_{i}+\varepsilon_{i}$

t-statistics in parentheses. ${ }^{* *}$ and * indicate statistical significance at $1 \%$ and $5 \%$ level respectively. All the values are measured in 1990 prices. $Y_{i t}$ and $Y_{i 0}$ are real GDP per capita in the ith province in 2003 and 1979 respectively in cross-section analysis. In panel data analysis, they are real GDP per capita in each ending year and beginning year of six time spans. Investment ratio $s$ equals investment/real GDP, population growth rate $n$ is the annual growth rate of the year-end population. $(g+\delta)$ equal 0.05 all the time. FDIR equals real actually used $\mathrm{FDI} /$ real total investment, ExpR is the ratio of real total value of export to real GDP, HEP human capital is the percentage of higher education enrolment/population. Tran, or transportation, is measured by equivalent highway mileage per $1,000 \mathrm{~km}^{2}$ of land area. East dummy is that takes the value of 1 for an eastern region and 0 otherwise.

Source: NBS (1999) and (NBS-CSY) various issues.

\subsection{Estimation results of $\beta$-convergence at regional level}

As discussed before, China can be divided into three macro-regions: east (coast), central, and west due to different conditions, such as geography, history, endowments, and economic development. To get an in-depth study on the issue of income disparity in China, it is necessary to estimate the process of convergence within each region apart from the estimation at the national level. Besides, it is well known that among the three regions, the east region is the richest and the west is the poorest. In other words, per capita income decreases from the east to the central, and then to the west, forming a clear three-tiered geographical pattern. Yao and Zhang (2001a) claim that the regional divergence is due to the spillover from the growth centres, which are highly concentrated in the east, and declines as provinces are further away from the centres. They find that the distance from the growth centre has a significant and negative effect 
on regional economic growth. Based on Yao and Zhang's finding, some related questions hence come into being. Will the west narrow its income disparity with the central and the east over time? Can the central areas catch up with the east over time? And how different is the pace of catching up with the east between the west and the central? Three groups combined with each pair regions are then re-estimated with the same models to answer these questions. Namely, three groups of economies, the east and the central (EC), the east and the west (EW), and the central and the west $(\mathrm{CW})$ are reconsidered in relation to the issue of convergence or divergence.

Since the panel data analysis has generated better results than the cross-section regression in the previous section, the following analysis will only use the panel data approach.

\section{Absolute income convergence}

Table 6 shows the estimation results of absolute convergence for the three regional groups. No clear evidence of absolute income convergence can be found in any of the regions and groups for the entire period 1979-2003. It means that the richer provinces in each region and the richer region in each group could manage to sustain their high pace of economic growth and keep out-performing their counterpart economies. In other words, the income of the poor economies in each region or group fails to catch up with the rich ones. In all the regressions, the $\mathrm{R}^{2}$ values are very small, showing little goodness-of-fit in the fitted models. This finding is consistent with the results presented in the previous section using national level data.

Table 6

Basic convergence regressions in panel data analysis for regional level, 1979-2003

\begin{tabular}{lccccccc}
\hline & \multicolumn{3}{c}{ Single region data } & & \multicolumn{3}{c}{ Group regions data } \\
\cline { 2 - 3 } \cline { 7 - 8 } Region & East & Central & West & & EC & EW & CW \\
\hline Constant & $0.376^{* *}$ & $0.319^{* *}$ & $0.299^{* *}$ & & $0.345^{* *}$ & $0.333^{* *}$ & $0.310^{* *}$ \\
& $(16.82)$ & $(19.29)$ & $(29.44)$ & & $(24.58)$ & $(26.33)$ & $(32.25)$ \\
LnY $_{i 0}$ & -0.008 & 0.025 & -0.002 & & 0.0109 & 0.0147 & 0.0169 \\
& $(-0.398)$ & $(1.024)$ & $(-0.104)$ & & $(0.776)$ & $(1.149)$ & $(1.104)$ \\
Implied $\lambda$ & 0.0003 & 0.0003 & 0.0001 & & -0.0004 & -0.0006 & -0.0007 \\
Adjusted $\mathrm{R}^{2}$ & 0.012 & 0.001 & 0.021 & & 0.003 & 0.003 & 0.002
\end{tabular}

Notes: Estimated equation: $\operatorname{Ln} Y_{i t}-\operatorname{Ln} Y_{i 0}=\operatorname{Cons} \tan t+\left(1-e^{-\lambda t}\right) \operatorname{Ln} Y_{i 0}+\varepsilon_{i}$, t-statistics in parentheses. ${ }^{* *}$ and ${ }^{*}$ indicate statistical significance at $1 \%$ and $5 \%$ level, respectively. $E C=$ all provinces in the east and central regions; $E W=$ all provinces in the east and west regions; $C W=a l l$ provinces in the central and west regions. The definitions of variables are the same to those in Table 2.

Source: NBS (1999) and (NBS-CSY) various issues.

\section{Conditional income convergence}

Like the conditional convergence analyses for the whole country, two steps of regressions are also conducted here to see the different effects of explanatory variables on the convergence process. In the first model by adding only investment ratio and effective population growth rate, as reported in columns 2-4 of Table 7, the findings are striking. Unlike the results for the whole country in Table 4, these two factors appear to be statistically significant with correct signs in all the three regions and have contributed to conditional income convergence in each region. Compared with Table 6 , the adjusted 
$\mathrm{R}^{2}$ values increase remarkably. These results imply that given a similar background in the region, more investment induces higher growth while a higher population growth prohibits growth. The speed of convergence shows remarkable improvement, rising to 0.32 per cent, 0.33 per cent and 0.24 per cent in the east, central and west, respectively. The east and central regions have similar values and the west has the smallest rate of convergence. It indicates that the provinces in the west will take a longer time to reach their own steady state.

The results of regional group analysis are exhibited in columns 5-7 in Table 7. The effective population growth rate is statistically significant for all groups and the investment ratio is significant for the east-central and central-west groups. Correspondingly, conditional convergence is detected within these two groups. It implies that there is a trend for the west to catch up with the central and the central to the east, but not the west to the east. This finding is similar to the regional analysis. Investment can enhance the speed of achieving their own steady states for the western provinces. However, it might not be important enough for them to catch up with those in the east. Furthermore, like the left panel, the implied $\lambda$ and the adjusted $\mathrm{R}^{2}$ have higher values. In short, the Chinese regions that received relatively more investment and have lower effective population growth rate have achieved higher income growth and will be able to shorten the time to catch up with their richer counterparts. In the eastwest group, these two factors do not seem to help the west catch up with the east. It might probably be explained by some other factors such as skill, knowledge, production experience, etc. that can affect economic performance. Without any improvement in these areas, the poorer provinces could still fail to exercise their full potential to grow at a higher speed.

Given another four variables in the second regression, the estimated results greatly improve (Table 8). Conditional convergence is observed in all the regions and groups, including the east-west group which is not found to have conditional convergence in Table 7. Besides, similar to those of national data, the additional four variables have brought about higher value of speed of convergence and the adjusted $\mathrm{R}^{2}$. Noticeably, the central region is found to be the biggest beneficiary with biggest improvement on the speed of convergence and $\mathrm{R}^{2}$. This can explain why the central region is observed to have the most equal income levels among its provinces from the estimation of $\sigma$-convergence. Furthermore, investment ratio and population growth rate are statistically significant in correct signs for all regions and groups. FDI ratio is only insignificant in the west region while export ratio is significant only to the west region, the east-central group, and east-west group. It indicates that FDI is a key determinant of regional growth differences and its effect is particularly strong among the provinces in the central region. This effect is insignificant among the west provinces, implying that there is little difference of growth that can be explained by FDI in western China. As mentioned earlier in the above section using national level data, the explanatory power of export ratio is diluted somewhat by FDI when they are estimated together, however, it is still found to have impact on growth, even stronger in the west region. As for human capital and transportation, similarly to the results using national data, these are not significant in any region or group. However, compared with the regression without these two variables, they have contributed to improving the explanatory power of export in the west region. Furthermore, they also helped the central and west regions to speed up the convergence process from 1.29 per cent to 1.51 per cent and 0.49 per cent to 0.56 per cent, respectively. This result indicates that better human capital and transportation 
Table 7

Conditional convergence regressions in panel data analysis for regional level, 1979-2003 by adding $L n(s)$ and $L n(n+g+\delta)$

\begin{tabular}{lccccccc}
\hline & \multicolumn{3}{c}{ Single region data } & & \multicolumn{3}{c}{ Group regions data } \\
\cline { 2 - 3 } \cline { 6 - 8 } Region & East & Central & West & & EC & EW & CW \\
\hline Constant & -0.145 & -1.284 & $-0.760^{*}$ & & -0.218 & -0.482 & $-1.17^{* *}$ \\
& $(-0.433)$ & $(-1.976)$ & $(-2.042)$ & & $(-0.804)$ & $(-1.754)$ & $(-3.450)$ \\
$L n Y_{\text {io }}$ & $-0.076^{* *}$ & $-0.078^{*}$ & $-0.059^{*}$ & & $-0.048^{*}$ & -0.0007 & $-0.048^{*}$ \\
& $(-2.878)$ & $(-2.064)$ & $(-2.148)$ & & $(-2.498)$ & $(-0.044)$ & $(-2.271)$ \\
$L n(s)$ & $0.231^{* *}$ & $0.158^{*}$ & $0.111^{*}$ & & $0.194^{* *}$ & 0.041 & $0.087^{*}$ \\
& $(3.231)$ & $(2.261)$ & $(2.294)$ & & $(3.729)$ & $(0.995)$ & $(2.424)$ \\
$L n(n+g+\delta)$ & $-0.310^{*}$ & $-0.659^{* *}$ & $-0.432^{* *}$ & & $-0.304^{* *}$ & $-0.315^{* *}$ & $-0.576^{* *}$ \\
& $(-2.617)$ & $(-2.800)$ & $(-3.126)$ & & $(-3.127)$ & $(-3.145)$ & $(-4.502)$ \\
Implied $\lambda$ & 0.0032 & 0.0033 & 0.0024 & & 0.0020 & 0.0000 & 0.0020 \\
Adjusted $R^{2}$ & 0.154 & 0.158 & 0.167 & & 0.132 & 0.068 & 0.161 \\
\hline
\end{tabular}

Notes: Estimated equation: $\operatorname{Ln} Y_{i t}-\operatorname{Ln} Y_{i 0}=$ Cons $\tan t+\left(1-e^{-\lambda t}\right) \operatorname{Ln} Y_{i 0}+\gamma_{1} \operatorname{Ln}(s)_{i}+\gamma_{2} \operatorname{Ln}(n+g+\delta)_{i}+\varepsilon_{i}$, t-statistics in parentheses. ${ }^{* *}$ and ${ }^{*}$ indicate statistical significance at $1 \%$ and $5 \%$ level respectively. $\mathrm{EC}=$ all provinces in the east and central regions; $E W=a l l$ provinces in the east and west regions; $\mathrm{CW}=$ all provinces in the central and west regions. The definitions of variables are the same to those in Table 4.

Source: NBS (1999) and (NBS-CSY) various issues.

Table 8

Convergence analysis with panel data by region 1979-2003 by adding $L n(s), L n(n+g+\delta)$, FDI, export, human capital and transportation

\begin{tabular}{|c|c|c|c|c|c|c|}
\hline \multirow[b]{2}{*}{ Region } & \multicolumn{3}{|c|}{ Single region data } & \multicolumn{3}{|c|}{ Group regions data } \\
\hline & East & Central & West & EC & EW & CW \\
\hline Constant & $\begin{array}{c}-1.348^{*} \\
(-2.404)\end{array}$ & $\begin{array}{c}-1.183^{*} \\
(-2.053)\end{array}$ & $\begin{array}{c}-1.065 \\
(-1.869)\end{array}$ & $\begin{array}{c}-0.740 * \\
(-2.482)\end{array}$ & $\begin{array}{l}-0.728^{* *} \\
(-2.859)\end{array}$ & $\begin{array}{c}-1.046^{*} \\
(-2.439)\end{array}$ \\
\hline $\operatorname{Ln} Y_{i 0}$ & $\begin{array}{c}-0.098^{*} \\
(-2.295)\end{array}$ & $\begin{array}{l}-0.315^{* *} \\
(-5.743)\end{array}$ & $\begin{array}{l}-0.130^{\star *} \\
(-3.502)\end{array}$ & $\begin{array}{l}-0.130^{\star *} \\
(3.868)\end{array}$ & $\begin{array}{l}-0.087^{* *} \\
(-3.007)\end{array}$ & $\begin{array}{l}-0.112^{* *} \\
(-3.594)\end{array}$ \\
\hline $\operatorname{Ln}(s)$ & $\begin{array}{r}0.173^{*} \\
(2.525)\end{array}$ & $\begin{array}{l}0.246^{* *} \\
(4.221)\end{array}$ & $\begin{array}{l}0.164^{* *} \\
(2.948)\end{array}$ & $\begin{array}{l}0.203^{* *} \\
(4.448)\end{array}$ & $\begin{array}{l}0.168^{* *} \\
(3.856)\end{array}$ & $\begin{array}{l}0.134^{* *} \\
(3.322)\end{array}$ \\
\hline $\operatorname{Ln}(n+g+\delta)$ & $\begin{array}{l}-0.427^{* *} \\
(-3.571)\end{array}$ & $\begin{array}{l}-0.763^{* *} \\
(-4.017)\end{array}$ & $\begin{array}{l}-0.579^{\star *} \\
(-2.875)\end{array}$ & $\begin{array}{l}-0.434^{* *} \\
(-4.667)\end{array}$ & $\begin{array}{l}-0.409^{* *} \\
(-4.459)\end{array}$ & $\begin{array}{l}-0.561^{* *} \\
(-3.727)\end{array}$ \\
\hline $\operatorname{Ln}(F D I R)$ & $\begin{array}{c}0.032^{* *} \\
(3.223)\end{array}$ & $\begin{array}{c}0.072^{* *} \\
(6.830)\end{array}$ & $\begin{array}{c}0.017 \\
(1.612)\end{array}$ & $\begin{array}{c}0.038^{* *} \\
(5.390)\end{array}$ & $\begin{array}{l}0.031^{* *} \\
(4.488)\end{array}$ & $\begin{array}{l}0.031^{\text {** }} \\
(4.209)\end{array}$ \\
\hline $\operatorname{Ln}(E x p R)$ & $\begin{array}{c}0.027 \\
(1.229)\end{array}$ & $\begin{array}{c}-0.007 \\
(-0.310)\end{array}$ & $\begin{array}{c}0.053^{*} \\
(2.127)\end{array}$ & $\begin{array}{c}0.023^{*} \\
(1.801)\end{array}$ & $\begin{array}{l}0.050^{* *} \\
(3.568)\end{array}$ & $\begin{array}{c}0.027 \\
(1.408)\end{array}$ \\
\hline $\operatorname{Ln}(H E P)$ & $\begin{array}{c}-0.062 \\
(-1.833)\end{array}$ & $\begin{array}{c}0.044 \\
(1.065)\end{array}$ & $\begin{array}{c}0.001 \\
(0.044)\end{array}$ & $\begin{array}{c}-0.018 \\
(-0.759)\end{array}$ & $\begin{array}{c}-0.032 \\
(-1.565)\end{array}$ & $\begin{array}{c}-0.005 \\
(-0.190)\end{array}$ \\
\hline Ln(Tran) & $\begin{array}{c}0.103 \\
(1.756)\end{array}$ & $\begin{array}{c}-0.015 \\
(-0.750)\end{array}$ & $\begin{array}{c}-0.018 \\
(-1.510)\end{array}$ & $\begin{array}{c}0.022 \\
(1.092)\end{array}$ & $\begin{array}{c}0.003 \\
(0.212)\end{array}$ & $\begin{array}{c}-0.007 \\
(-0.583)\end{array}$ \\
\hline Implied $\lambda$ & 0.0041 & 0.0151 & 0.0056 & 0.0056 & 0.0037 & 0.0048 \\
\hline Adjusted $\mathrm{R}^{2}$ & 0.315 & 0.563 & 0.248 & 0.373 & 0.343 & 0.281 \\
\hline
\end{tabular}

Estimated equation:

$\operatorname{Ln} Y_{i t}-\operatorname{Ln} Y_{i 0}=$ Cons $\tan t+\left(1-e^{-\lambda t}\right) \operatorname{Ln} Y_{i 0}+\gamma_{1} \operatorname{Ln}(s)_{i}+\gamma_{2} \operatorname{Ln}(n+g+\delta)_{i}+\gamma_{3} \operatorname{Ln}(F D I)_{i}$

$+\gamma_{4} \operatorname{Ln}(\text { Export })_{i}+\gamma_{5} \operatorname{Ln}(H E P)_{i}+\operatorname{Ln}(\operatorname{Tran})_{i}+\varepsilon_{i}$

t-statistics in parentheses. ${ }^{* *}$ and * indicate statistical significance at $1 \%$ and $5 \%$ level, respectively. $\mathrm{EC}=$ all provinces in the east and central regions; $\mathrm{EW}=$ all provinces in the east and west regions; $\mathrm{CW}=$ all provinces in the central and west regions. The definitions of variables are the same to those in Table 5.

Source: NBS (1999) and (NBS-CSY) various issues. 
are necessary factors of growth and similar other factors, they had more influence on the process of catching-up for the central region although they were not as powerful as other explanatory variables. This finding is consistent with those found in the national analyses. The models are re-estimated excluding some other factors and transportation is observed to be significant in some regions and groups but human capital is always insignificant. The different contributions of six variables to the catching-up process reveal that China's economic growth in the past has been greatly dependent on intensive material inputs and capital investments. Human capital and technology have played a relatively minor role. This implies that human capital has not been fully exploited in the production process, or the distribution of human capital across regions may not be as uneven as that of other variables, especially FDI and exports.

\section{Conclusion}

Compared with previous studies, this article makes a new contribution to the understanding of the impact of FDI on regional growth and inequality in China after economic reform. It uses a more recent dataset for all the Chinese regions during 1979-2003, employing both cross-section and panel data approaches to study the same question. It examines regional inequality from three different perspectives: interprovince, intra-region, and inter-group (each pair of two regions). It employs more determinants of income growth such as FDI and transportation into the $\beta$-convergence estimation, with special attention on FDI and its role in the economic convergence process across the country and within each geo-economic region as well as regional groups. The purpose of examining the same issue of FDI on spatial growth differences and income inequality with various model specifications and estimations is to provide a comprehensive anatomy on whether FDI has caused regional income inequality, which is a controversial issue in the literature with significant policy implications on the economic growth and development of China and any other similar less developed economy in the world.

Apart from $\beta$-convergence, $\sigma$-convergence with the coefficient of variation $(\mathrm{CV})$ is used to assess whether there is $\sigma$-convergence between China's regions. The results show that the country has experienced three phases in the process of income inequality over 19792003, declining in the first decade, expanding in the second and then starting to decline again from the third decade. However, this slight decline in CV may not be statistically significant as $\mathrm{CV}$ is a non-parametric approach that is not subject to statistical testing. Furthermore, a declining $\mathrm{CV}$ does not necessarily imply economic convergence if the reduced $\mathrm{CV}$ is not caused by the poorest regions catching up with the richest regions, but by the catching up of the medium-income regions with high-income ones, or by the convergence among the medium income regions. As a result, CV is not an ideal measurement for income convergence for all regions within a country although it can be used to indicate the trend of overall inequality. The last disadvantage of $\mathrm{CV}$ is that it cannot show why regions are converging or diverging in per capita incomes.

In contrast, $\beta$-convergence is a more useful tool to measure income convergence as it can testify whether poor regions are catching up with rich ones. It can also explain why regions are converging or diverging in per capita incomes. In this paper, the

$\beta$-convergence test indicates no evidence of absolute convergence in different estimations with both the cross-sectional and pooled analyses. This implies that the 
initially poorer regions have failed to grow faster than the initially richer ones due to their diversified economic backgrounds and the biased policies faced by these economies. It implies that neither the poor provinces nor poor regions have managed to grow faster than their rich counterparts. As a result, it can be concluded that regional inequality has risen rather than declines during the data period.

But what explains the rising inequality? This question can be answered through the analysis on conditional convergence. The analysis in this paper provides some striking findings on income inequality. First of all, apart from investment ratio and effective population growth rate, FDI and export are found to have significant and positive effects on regional growth differences. In addition, the effect of FDI on economic growth is weak among the western provinces. These two findings could easily lead to a conclusion that FDI is an important cause of regional inequality, especially if one considers that the skewed distribution of FDI among the three large geo-economic regions in China coincides with a similar spatial pattern of real per capita GDP. If such a conclusion were the correct interpretation of the results and logical as many previous studies argue and suggest, then reducing FDI inflows into China would be able to restrain the rising trend of regional income inequality. Such a policy implication would also make it difficult to reconcile the positive effect of FDI on economic growth and its 'negative' effect on income distribution. As such a conclusion and its potential policy implications are obviously controversial, it needs a better understanding and a more accurate interpretation of the econometric results that show a positive and significant relationship between FDI and economic growth in all kinds of model specifications presented in this paper.

If we summarize the results presented in this paper, we have the following findings: (i) regional income inequality rises in the data period; (ii) regions can converge to their own steady states only after controlling for the differences in saving rate, population growth, human capital endowment, transportation, and above all FDI and exports; (iii) the same factors that have a significant effect with national level data have similar effect with regional (or groups of regions) level data; (iv) FDI is singled out to have played a consistent and positive effect on growth differences in all specifications except for the west region and the combined west/central regions; and (v) FDI is highly unevenly distributed among the regions, with a very small share in the west region. All these findings should point to the following conclusion which is very different from that drawn by many other authors: FDI is an important factor of economic growth but it is unevenly distributed across regions. As a result, it is the uneven distribution of FDI, rather than FDI itself, that has been a cause of regional income inequality. This conclusion should be followed with the following policy implication: to reduce regional inequality, FDI should be encouraged, rather than discouraged, but FDI has to be directed towards to the west and central regions through preferential policies and government intervention to create a better environment for absorbing FDI in these relatively backward areas. 


\section{References}

Bao, S., G. H. Chang, J. D. Sachs, and W. T. Woo (2002). 'Geographic Factors and China's Regional Development under Market Reforms, 1978-1998'. China Economic Review, 13 (1): 89-111.

Baumol, W. J. (1986). 'Productivity Growth, Convergence, and Welfare: What the Long-Run Data Show'. American Economic Review, 76 (5): 1072-85.

Cannon, T. (1990). 'Regions'. In T. Cannon and A. Jenkins (eds), The Geography of Contemporary China. London: Routledge, 28-60.

Chai, J. (1996). 'Divergent Development and Regional Income Gap in China'. Journal of Contemporary Asia, 26 (1): 46-58.

Chang, G. H. (2002). 'The Cause and Cure of China's Widening Income Disparity'. China Economic Review, 13: 335-40.

Chen, J., and B. M. Fleisher (1996). 'Regional Income Inequality and Economic Growth in China'. Journal of Comparative Economics, 22 (2): 141-64.

Chen, Y., and S. Démurger (2002). 'Foreign Direct Investment and Manufacturing Productivity in China'. CEPII Research Project on 'The Competitiveness of China's Economy'. Available at: http://www.bm.ust.hk/ ced/Yu\%20CHEN.pdf.

Chen, G., and C. Wu (2005). 'Introduction: Trapped Between Reality and Expectations'. The Chinese Economy, 38 (1): 8-13.

Démurger, S. (2001). 'Infrastructure Development and Economic Growth: An Explanation for Regional Disparities in China?'. Journal of Comparative Economics, 29 (1): 95-117.

Dollar, D., and A. Kraay (2002). 'Growth is Good for the Poor'. Journal of Economic Growth, 7 (3): 195-225.

Fleisher, B. M., and J. Chen (1997). 'The Coast-Noncoast Income Gap, Productivity, and Regional Economic Policy in China'. Journal of Comparative Economics, 25 (2): 220-36.

Fu, X. (2004). 'Limited Linkages from Growth Engines and Regional Disparities in China'. Journal of Comparative Economics, 32 (1):148-64.

Gundlach, E. (1997). 'Regional Convergence of Output per Worker in China: A Neoclassical Interpretation'. Asian Economic Journal, 11 (4): 423-42.

Gustafsson, B., and L. Shi (2002). 'Income Inequality within and across Counties in Rural China, 1988 and 1995'. Journal of Development Economics, 69 (1): 179-204.

Huo, S. (1994). 'Regional Inequality Variations and Central Government Policy, 1978-1988'. In J. Hao and Z. Lin (eds), Changing Central-Local Relations in China. Boulder, CO: Westview Press, 182-206.

Hsueh, T. T. (1994). 'Pattern of Regional Development in the People's Republic of China'. Asian Economic Journal, 8 (1): 1-38. 
Jian, T., J. D. Sachs, and A. M. Warner (1996). 'Trends in Regional Inequality in China'. China Economic Review, 7 (1): 1-21.

Jones, D. C., C. Li, and A. L. Owen (2003). 'Growth and Regional Inequality in China during the Reform Era'. China Economic Review, 14 (2): 186-200.

Kato, H. (1992). 'Regional Development in the Reform Period'. In R. Garnaut and G. Liu (eds), Economic Reform and Internationalization. London: Allen \& Unwin, 116-36.

Kueh, Y. Y. (1989). 'The Maoist Legacy and China's New Industrialization Strategy'. China Quarterly, 119 (Special Issue): 420-47.

Lakshmanan, T. R., and C. Hua (1987). 'Regional Disparities in China'. International Regional Science Review, 11 (1): 97-104.

Liu, X. (2000). 'Comparative Productivity of Foreign and Local Firms in Chinese Industry'. In Proceedings of UK Chapter of the 27th AIB Conference, vol. 2. 115-36.

Liu, X., H. Song, Y. Wei, and P. Romilly (1997). 'Country Characteristics and Foreign Direct Investment in China: A Panel Data Analysis'. Weltwirtschaftliches Archiv, 133 (2): 311-29.

Lyons, T. P. (1991). 'Interprovincial Disparities in China: Output and Consumption, 1952-1987'. Economic Development and Cultural Change, 39 (3): 471-506.

Mankiw, N. G., D. Romer, and D. N. Weil (1992). 'A Contribution to the Empires of Economic Growth'. The Quarter Journal of Economics, 107 (2): 407-37.

Mazur, J. (2000). 'Labour's New Internationalism'. Foreign Affairs, 79 (1): 79-93.

NBS (National Bureau of Statistics) (1999). China Statistical Data of 50 Years. Beijing: Statistical Press.

NBS-CSY (1999-2004). China Statistical Yearbook, various issues. Beijing: Statistical Press.

Raiser, M. (1998). 'Subsidising Inequality: Economic Reforms, Fiscal Transfers and Convergence across Chinese Provinces'. Journal of Development Studies, 34 (3): 126.

Sala-i-Martin, X. (1996). 'Regional Cohesion: Evidence and Theories of Regional Growth and Convergence'. European Economic Review, 40 (6): 1325-52.

Solow, R. M. (1956). 'A Contribution to the Theory of Economic Growth'. Quarterly Journal of Economics, 70 (1): 65-94.

Sun, H., and J. Chai (1998). 'Direct Foreign Investment and Interregional Economic Disparity in China'. International Journal of Social Economics, 25 (2/3/4): 424-47.

Swan, T. (1956). 'Economic Growth and Capital Accumulation'. Economic Record, 32: 334-61.

Tsui, K. Y. (1991). 'China's Regional Inequality, 1952-1985'. Journal of Comparative Economics, 15 (1): 1-21.

Tsui, K. Y. (1996). 'Economic Reform and Interprovincial Inequality in China'. Journal of Development Economics, 50: 353-68. 
Wu, Y. (2002). 'Regional Disparities in China: An Alternative View'. International Journal of Social Economics, 29 (7/8): 575-88.

Xu, L. C., and H. F. Zou (2000). 'Explaining the Changes of Income Distribution in China'. China Economic Review, 11 (2): 149-70.

Yang, D. (1990). 'Patterns of China's Regional Development Strategy'. China Quarterly, 122 (June): 230-57.

Yang, D. (1991). 'Reforms, Resources, and Regional Cleavages'. Issues and Studies, 27 (9): 43-69.

Yao, S. (1999). 'Economic Growth, Income Inequality and Poverty in China under Economic Reforms'. Journal of Development Studies, 35 (6): 104-30.

Yao, S., and K. Wei (2007). 'Economic Growth in the Presence of FDI: The Perspective of Newly Industrializing Economies'. Journal of Comparative Economics, 35 (1): 211-34.

Yao, S., and Z. Zhang (2001a). 'On Regional Inequality and Diverging Clubs: A Case Study of Contemporary China'. Journal of Comparative Economics, 29 (3): 466-84.

Yao, S., and Z. Zhang (2001b). 'Regional Growth in China under Economic Reforms'. Journal of Development Studies, 38 (2): 167-86.

Zhang, Z. (2001). 'Trade Liberalization, Economic Growth and Convergence: Evidence from East Asian Economies'. Journal of Economic Integration, 16 (2): 147-64.

Zhang, X., and K. H. Zhang (2003). 'How Does Globalization Affect Regional Inequality within a Developing Country? Evidence from China'. Journal of Development Studies, 39 (4): 47-67.

Zheng, F., L. D. Xu, and B. Tang (2000). 'Forecasting Regional Income Inequality in China'. European Journal of Operational Research, 124: 243-54. 